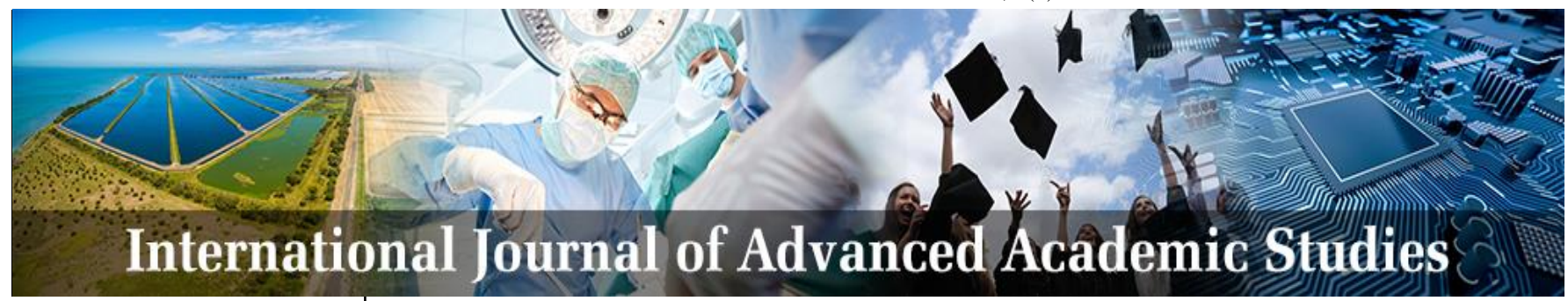

E-ISSN: 2706-8927

P-ISSN: 2706-8919

www.allstudyjournal.com IJAAS 2020; 2(3): 264-271

Received: 12-05-2020

Accepted: 14-06-2020

Dr. Abroo Aman Andrabi Assistant Professor, School of Humanities and Social Sciences, Jamia Hamdard, New Delhi, India

\section{Interfaith dialogue: its need, importance and merits in the contemporary world}

\section{Dr. Abroo Aman Andrabi}

DOI: $\underline{\text { https://doi.org/10.33545/27068919.2020.v2.i3d.157 }}$

\begin{abstract}
World is the birthplace of many faiths and has accommodated and nourished multiple religions. It has provided a common roof to major religions for their sustenance and growth. The intricate mosaic of diverse faiths, beliefs, traditions and languages in many countries is indeed amazing.

Today, when the world has attained a great technological progress and scientific achievements, it is disconcerting to say that the people are making disputes in the name of religion. Thousands of people are killed, nations have been divided, and even the holy centres of worship have been demolished in the name of religion. Communitarianism feelings are increasing day by day in the hearts of the followers of different religions. In this era of confusion and distressed life, where we grow more afraid than the previous day, hour, minute or second, afraid of our neighbours, our folks, our society, to other's beliefs and even to our own selves. What is the solution to protect the humanity from this appalling condition? The only solution would be interfaith dialogue which is mandatory if not dynamic for everyone to have the understanding of different religions or belief systems. In this article I would start with a brief introduction about interfaith dialogue, and then discuss in detail the need, importance and merits of interfaith dialogue in the contemporary world. This would give an understanding of the dialogue between Hindus, Muslims, Christians, and Sikhs and would benefit in removing prejudices and misunderstandings about each other faith. It would also help to realize common objectives such as the establishment of justice and world peace, the protection of families from disintegration, the protection of human rights and the promotion of moral values.
\end{abstract}

Keywords: Interfaith, dialogue, need, importance, merits, contemporary, world, misunderstanding, justice, peace, disintegration, protection, moral values

\section{Introduction}

Interfaith is relating to or involving different religions or members of different religions being together. Dialogue means a discussion between people in which opinions are exchanged. The theoretical dialogue in which the leaders of religions express the viewpoints of their religion which help people and leaders themselves to have a good knowledge about the other religion.

What Is Interreligious Dialogue? Interfaith dialogue, also referred to as interreligious dialogue, is about people of different faiths coming to a mutual understanding and respect that allows them to live and cooperate with each other in spite of their differences. The term refers to cooperative and positive interaction between people of different faiths/religious traditions, at both the individual and institutional level. Each party remains true to their own beliefs while respecting the right of the other to practise their faith freely. Interfaith dialogue is not just words or talks, it includes human interaction and relationships. It can take place between individuals and communities and on many levels. For example, between neighbours, in schools and at our workplaces - both in formal and informal ways.

Dialogue therefore, is not just something that takes place on an official or academic level only - it is part of daily life during which different cultural and religious groups interact with each other directly, and where tensions between them are the most tangible.

As per the Wikipedia definition of "interfaith dialogue", it's a cooperative and positive interaction between people of different religious faiths and spiritual or humanistic beliefs, at both the individual and institutional level with the aim of deriving a common ground in belief through a concentration on similarities between faiths, understanding of values, and commitment to the world.

Interfaith dialogue has a range of meanings, all of which involve ways in which we handle our encounters with religious difference-dialogue in daily life, dialogue in
Dr. Abroo Aman Andrabi Assistant Professor, School of Humanities and Social Sciences, Jamia Hamdard, New Delhi, India 
learning, dialogue in community, and dialogue in faith and theology. Interfaith dialogue is a challenging process by which adherents of differing religious traditions encounter each other in order to break down the walls of division that stand at the centre of most wars. The objective of interreligious dialogue is peace.

Hans Kung ends his book Global Responsibility with these words:

"No human life together without a world ethic for the nations.

No peace among the nations without peace among the religions.

No peace among the religions without dialogue among the religions."1

Interfaith dialogue has many faces. Two people can come together and share the aspects of their respective faiths and struggle to understand that which is foreign. Theologians can write papers, publish in journals, and convene to discuss the finer theological issues related to interreligious dialogue (and there are a multitude of theological issues). Perhaps members of one faith tradition can join with members of another religion to improve a neighbourhood.

But, Interfaith dialogue has been a very controversial issue and there have been a lot of discussions about it; its necessity, rationale, and success. These questions have made it obvious that people are not aware of the real meaning of interfaith dialogue.

Perelman and Olbrechts- Tyteca explain dialogue as follows: "... (it) is not supposed to be a debate ... but rather a discussion in which the interlocutors search honestly and without bias for the best solution to a controversial problem".2 Related to this description, Fethlluh Gulen describes interfaith dialogue as "... seek(ing) to realize religion's basic oneness and unity, and the universality of belief. Religion embraces all beliefs and races in brotherhood, and exalts love, respect, tolerance, forgiveness, mercy, human rights, peace, brotherhood, and freedom via its Prophets".3

These descriptions raise another question: how useful and beneficial can interfaith dialogue be in solving problems? Interfaith dialogue does not aim to change the ideas of people about their religions or faiths, but seeks to find common ground between religions, to focus on communities, and through an emphasis on harmony and peace, find solutions to many of our common problems. In fact, one of the reasons for interfaith dialogue is to "provide an atmosphere of freedom" as Ahmet Kurucan states. "Dialogue between followers of different faiths gives them the opportunity to talk to and listen to each other, getting to know and learning to understand the 'other'. In interfaith dialogue we try to approach our partners in a spirit of tolerance, truthfulness, sincerity, love, respect and good will, without willing the other to accept our own beliefs or ideas". 4

Rev. Allman states, "The ability to discuss our religious and cultural differences is more than an 'extra-curricular activity'; it is a skill which is vital for participants in democracy, especially a democratic society such as ours, which is filled with people whose differences are deep and complex" 5

These statements show the importance of interfaith dialogue for the improvement of humanity and the goodwill of societies. Henrique Pinto highlights the role of interfaith dialogue in today's society as "...an inevitable fact of our being-with-other-faiths." 6

In connection to this, Leonard Swidler states that, "In the past, during the age of divergence, we could live in isolation from each other; we could ignore each other. Now, in the age of convergence, we are forced to live in one world. We increasingly live in a global village" 7

The history of interfaith dialogue is as ancient as the religions since men and women when not at war with their neighbours have always made an effort to understand them (not only because understanding is a strategy for defiance, but also to delay the dialogue wars). History records many examples of interfaith initiatives and dialogue throughout the ages.

Interfaith dialogue and action have taken place for many centuries. For example, the Emperor Jalāl al-Dīn Muhammad Akbar the greatest of the Mughal emperors of India, reigned from 1556 to 1605 and encouraged tolerance in Mughal India, a diverse nation with people of various faith backgrounds, including Islam, Hinduism, Sikhism, and Christianity. In order to preserve the unity of his empire, Akbar adopted programs that won the loyalty of the non-Muslim populations of his realm. He reformed and strengthened his central administration and also centralized his financial system and reorganized tax-collection processes. Although he never renounced Islam, he took an active interest in organising discussions about other religions, persuading Hindus, Paresis, and Christians, as well as Muslims. He himself was an illiterate but he always encouraged scholars, poets, painters, and musicians, making his court a centre of culture. Muslim Spain is an additional historical example of great religious pluralism. Another example of historical coexistence between people of different faiths has been in the Balkans under the administration of the Ottoman Turks from 15th to 19th centuries. Catholic and Orthodox Christians as well as Muslims, Jews and Sufis have dwelled in harmony for hundreds of years in this region.

Therefore, the Interfaith dialogue, refers to an exchange among religious communities on issues of mutual concern, determines the 'engagement of the world's religious traditions around theological questions and in their efforts to collaborate on questions of peace, human rights, economic and social development'.8

\section{Need for interfaith dialogue}

Dialogue between followers of different faith traditions has become an urgent necessity today. Undoubtedly, in today's world inter-community harmony is a major need, and the lack of it has emerged as a major challenge. Inter-faith and inter-community harmony must be built on the foundations and concerns that different faith communities share in common. It must also seek to build bridges of understanding between these communities, and to eliminate misunderstandings that are a major source of intercommunity conflict. It is also important to highlight the need for interfaith dialogue: if they are to contribute to peace, religions should give some thought to how they handle manifestations of their own internal diversity, as part of a genuine culture of pluralism

It would be engaged in the following activities: raising awareness of and addressing violence against women through workshops, training and counselling; providing chaplaincy in hospitals and prisons; initiating research into 
human rights issues and the protection of sacred sites during times of conflict; participating in many interfaith and intra-faith initiatives as a signatory to international faith declarations such as the Amman Message (The Amman Message is a statement calling for tolerance and unity in the Muslim world that was issued on 9 November 2004 (27th of Ramadan $1425 \mathrm{AH}$ ) by King Abdullah II bin Al-Hussein of Jordan.) and the "A Common Word" initiative (A Common Word between Us and You is an open letter, dated 13 October 2007, from leaders of the Islamic religion to leaders of the Christian religion. Every year in February thousands of people all over the world gather in celebration of the World Interfaith Harmony Week, an extension of the A Common World initiative. (Start of by sending a letter of support and then organize an event; raising standards and promoting interfaith dialogue in national forums, such as the Mosques and Imams National Advisory Board, The Inter Faith Network for United Kingdom (Allowing good practice in mosques and Islamic teaching institutions through a set of core standards related to governance, personnel, participation of women and youth, and civic responsibility on which the member organisations self-regulate). Since tension and conflict may arise not only between those who profess different religions but also between factions within the same religion, Dialogue between followers of different faith traditions should also be encouraged in order to foster harmony among those who profess the same religion.

The purpose of interfaith dialogue is to increase our understanding and respect for other religious systems and institutions, thereby increasing our appreciation of their values. Dialogue should enhance our sensitivity to the feelings of all professing religious people in their relationship with God. Good dialogue should, in addition, result in the deepening of the faith of every participant.

There is valid purpose in dialogue regarding an issue which could become desirable or even mandatory for interfaith action as the result of the dialogue. There is, however, valid purpose as well in dialogue which takes place for its own sake - for the elucidation of subjects and for the forthcoming of the persons and feelings of the participants. Interfaith dialogue is possible only when two convictions pre-exist in the participants. No participant is seeking to proselytize any other participant. The participants are persuaded of the inherent validity and integrity of all the faith groups involved in the dialogue and are persuaded that no group possesses total and absolute knowledge regarding the nature and works of God and human involvement with the Divine.

Interfaith dialogue can be an excellent way to heal divisions in society. Social science research indicates that having a positive, meaningful relationship with someone of a different background and learning about their identity correlates to viewing that person's entire group more favourably. The same logic applies with interfaith conversations. Interfaith dialogue is also needed to strengthen the citizenship rights. This is needed because there is deep rooted misconception among the minorities particularly Muslims in India that they are denied the rights as a citizen of this country. This alleged discrimination starts from getting admission in school, finding jobs, finding an apartment and other such likes. These real or imagined perception, has led to suspicion among Muslims that they are being discriminated on the basis of their religion. An interfaith dialogue is necessary to allay such mistrust and to promote social equality between different communities.

Interfaith dialogue should also be initiated to weed out communal politics that rule the roost even in the so called secular political parties. What may emerge from such dialogue is to pressurize the political parties to give adequate representation to the people belonging to different faith and nurture leaders from different faiths and their organization. This effort would not only strength democracy but also improve social relationship in the country.

"There will be no peace among the nations without peace among the religions. There will be no peace among the religions without dialogue among the religions," 9 Interfaith dialogue is becoming commonplace these days and many organizations are pursuing it in view of inter-religious tensions in many countries of the world.

Increasingly, international governments have witnessed the need to understand religious sensitivities as a way to maintain international relations and cooperation with different states. Religions were revealed or found for all round peace and progress of humanity. It tried to relieve humanity from the clutches of vicious deeds and aimless proceedings. The religious leaders were among the top individuals in society who exert their thought and action for the overall spiritual and material development of humanity. They were in the field of science and economics as well as in the field of religion. Today religion and culture have been bisected by the secular culture. Now religious leaders have limited their sphere of influence only to the world of the knowledge of religious scriptures. It is the duty of religious leadership to extend their sphere of influence to all fields of human development and erase the gap between religious and secular world.

The effective implementation of the strategies mentioned above by religious leadership will help to extend their sphere of influence. Adequate attention will be given to the development of spiritual leadership with modern talents and influence in different fields of human development. Such leadership can lead the humanity with harmony and peaceful co-existence.

If we take into consideration the fact that in most states, it is predominately religious minorities that are being oppressed, it becomes clear that the only way to prevent religious oppression is to ensure the right to freedom of religion or belief for all, whether one belongs to the majority or minority groups. The majority group plays a critical role in addressing the discrimination of minorities. Their influence on the situation for minority groups cannot be downplayed. Hence, today, more than ever, it is crucial to open an interfaith dialogue.

There should be a network of religious and community leaders committed to religious and communal harmony, who will be vigilant about the communal tensions in every locality. This network can meet the tensions sprout in any locality and prevent the break out of clashes. This network can meet police, administrative and law authorities to keep religious harmony intact. Whenever religious and communal leaders are trying hand in hand to prevent communal clashes from breaking out it will control the peaceful co-existence to a great extent.

\section{Importance for interfaith dialogue}

Dialogue between followers of different faith traditions is very important to promote and propagate peace and 
corporation among different religions and cultures. Multi culture or the diversity in religions all over the world is an accepted fact which demands peace and tolerance. It demands mutual respect, mutual understanding and coexistence in religions, and all the religions must come out of their choice. Almighty God has commanded not to use any kind of compulsion in the followers of one faith. It is not allowed to try to impose one's faith on others.

In India to the decade of the 1980s and 1990s, also the years of 2002 and 2020 saw the eruption of communal violence and several major riots took place. There is all possibility to be misguided by evil behaviours. So the youth has to divert all of their efforts towards making of a peaceful society from bottom-up.

Indians realized the importance of interfaith dialogue and many such meetings took place. Since the decade of nineties and beginning of $21^{\text {st }}$ century the world has witness various tension due to religious clashes and expansion of extremist and fundamentalist organizations result a danger to world peace. So, the only way to minimize the religious tension and a peaceful civilized society is to promote interfaith dialogue between various faiths of the society which would help each religion to grow and develop mutually. Each religion through dialogue helps other religion for its enrichment, and provides space for the religions to contribute and complement each other. It is and should be very important to me and my countrymen because we live in a secular country - India, where not all religions are the same, there exists a myriad of differences, however there is dignity in differences and this is a central tenet of the interfaith movement.

Interfaith dialogue is an exercise of learning about those that are radically different from me and my community and learning to coexist with those who subscribe to different beliefs, customs, and worldviews other than my own. It also serves to strengthen my own faith identity. It is one thing to describe my beliefs to another person that already comes pre-wired with a set of similar vocabulary and understanding of social constructs to interpret what I am saying within similar parameters to how I myself perceive it. However, it is an entirely different game when I have to explain my faith to someone outside of my faith. I have to use different vocabulary, I am pushed to own what I am saying, search and find different forms to articulate particular truths. I am stretched. I am also amazed to learn similar teachings of others, for example, creation in Islam or Judaism, and consequently in that interaction of learning my own resources are then amplified.

These days most of the common reasons for disagreement between religions, or between people of different faiths, are that they do not understand one another's beliefs or ideas. Interfaith dialogue meetings, panels, conferences help these misconceptions and unfamiliarity to disappear, and the result of such dialogues can be tremendous. As Smock states, "... when two or more faiths come together to explore or promote the possibility of peace, the effects can be especially potent." 10 So, whether you are Christian, Hindu, Muslim, Jewish, Atheist, Agnostic or anything else, the interfaith dialogue is a place where anyone of us can learn how to be aware of religious/non-religious stigmas, strengths and differences. Learning creates a place for debate and dialogue, both of which are important means of cooperation. One problem that often brings misunderstandings and prejudices comes from the languages we use to identify people. The power of generalizing a subject into the same realm as others allows for bigotry to distribute easily. In fact, history has taught us that generalizing language is a powerful tool that some of the most notorious world leaders used to further their own agendas.

Contrary to popular belief, most faiths (and even non-faiths) have more in common than many people think. While there are many doctrines in major religions around the world that claim to be the one and only path, there are also aspects to those same religions that encourage peace, cooperation and compassion. Christianity, Judaism and Islam are all monotheistic. Likewise, nearly every major religion incorporates a section about loving others.

Now let us see the importance and result of talking about religious differences. The religious situation today in India is complex, and one of the most important reasons for that complexity are the many and diverse religions. The world is filled with different religions, and these differences raise a moral question: How can people who have different and sometimes competing visions of reality live together in peace?

The effort to bridge the gaps in understanding between religions has led to efforts at inter-religious dialogue. We see such efforts in inter-religious dialogue going on between Christians and Buddhists, Muslims, Hindus and Jews, and many other combinations. The purpose of these dialogue efforts is not to reduce religion to some common affirmation like "we all believe the same thing," for this is neither true nor helpful to prompting understanding. Different religions believe and practice different things, and in dialogue, those differences become the objects of discussions.

When people can talk about differences, they can move beyond the content of those differences - the notoriously difficult theological content - to see before them another human being who is, like them, living in a community, offering respect and expecting it from others, and seeking meaning and purpose through a vision of a transcendent reality.

When people are talking about differences, they are learning. When they are talking, they are not killing like what happened recently in India (The 2020 Delhi riots, or North East Delhi riots, were multiple waves of bloodshed, property destruction, and rioting began on $23^{\text {rd }}$ of February, originating in Jaffrabad). Dialogue between followers of different faith traditions and the exchange of perspectives is an essential thing indeed. Though dialogue does not solve all problems or bridge all gaps, but its importance is really in creating a space for conversation where differences can be peacefully and respectfully confronted and understood. Dialogue fails if people pretend differences doesn't exist.

Despite the differences in worship and theology, all religions share a common teaching which is peace. The interfaith dialogue provides strong foundations for a greater understanding of different religions in an effort to promote peace. Considering the rising influence of non-state actors in international relations, and their interpretations-or misinterpretations - of religion, it seems logical that by continuous and unified calls for peaceful coexistence, society can ensure that acts of violence will not be misrepresented under the guise of religion.

People are required to overcome inter-group tensions and their potential negative outcomes through good will and the 
commitment to live together in peace and justice with their fellow human beings, whatever the odds. In other words, the response to diversity through positive engagement or dialogue is one of the major goals that the divine will has set for humankind.

It is therefore truly paramount today for opportunities to be created for religious leaders to exchange ideas and develop peace initiatives using their respective religious teachings to influence their faithful. These types of gatherings will help to protect "society and territories from violence, extremism and terrorism, and to eliminate chances of clashes and warfare." India's father of Nation Mahatma Gandhi believes in an inclusive theory of interfaith dialogue as he says "I do not want my house to be walled in on all sides and my windows to be stuffed. I want the culture of all lands to be blown about my house as freely as possible." 11 . He welcomes winds from all cultures to blow into his house, which means faith drew from every religion, and all inclusive. The modern ideologies such as Communism, Capitalism, Secularism, Liberalism, Modernism, PostModernism and so on have assumed the form of virtual religions. For inter-faith dialogue initiatives to be more effective, these ideologies also need to be carefully studied. And beyond that, it is even essential to faith and to live a religious life well.

Dialogue between followers of different faith traditions provide a frame reference to shape one's identity. Knowing the faith of others, will help one to improve his selfidentification. In America the issues of identity between black and white is still going on. No single crisis or event in recent history has so sharply magnified the country's racial disparities and inequities as the coronavirus. But the George Floyd's death at the hands of a police officer in Minneapolis triggered protests across the United States and brought renewed attention to ongoing concerns about systemic racism in the criminal justice system. The slaying, in the midst of a pandemic that has disproportionately infected and killed black people, has exposed long-standing racial inequities in every aspect of American life.

Centuries of racism and discrimination mean that this divide is a great deal wider for black households that are denied the access to the opportunities and resources available to white households. It is a subject of lack of communal harmony in the society. Before fourteen hundred years the constitution of the new state (Madinah) established under the regime of prophet Muhammad (peace and blessings be upon him) was the first written constitution in the world dealing with a pluralistic society. It was based on the principles of unity, justice, peace, mutual support and co-operation -exertion and respect and fulfilment of commitments. The Jews and Christians in Madinah enjoined full freedom of religion and were even allowed to be governed by their own laws and even have their own judges. The Prophet (peace and blessings be upon him) offered even territorial autonomy and self -government to the Christians of Najran. History reports that Jews flourished vastly during the Muslim regime. Jews fled from Christian persecution to Muslim countries for refuge. Prophet Muhammad (peace and blessings be upon him) treated the Christians who came from Najran in the year $10 \mathrm{H}$ with utmost courtesy. He even allowed them to pray in Madinah mosque with their religious rites. This shows mutual respect is more important than tolerance. The respect and reverence to other religions can be engendered through the process of socialization. The socialization agents in society should be sustained in a way that it creates a society which respect the followers of other religions. Parents, Peer groups, religious leadership, education, media etc. plays a dynamic role in socializing the people and generating the mutual respect. The leaders should discourage their followers from the usage of words and writings which harm the feelings of the followers of other religions.

It is the value and duty asserted in the society that no one shall be discriminated against because of his gender, colour, caste or faith. The discrimination by the leaders or authorities invokes to inspire inferiority feeling in the discriminated community and at last they resort to the means of violence. If there is group of leaders who were vigilant in the development of nation and community, they can talk peacefully with authorities and pressure for the just actions.

\section{Merits for interfaith dialogue}

There are a number of valuable benefits. If we agree that dialogue is a religious requirement, then dialogue contributes to the fulfilment of our religion. If we agree that dialogue is a natural expression of our innate human disposition (fitra), then dialogue enriches our experience as human beings.

The merits of Dialogue between followers of different faith traditions can be listed as follows:

- Interfaith dialogue demonstrates to the public how different faiths can live together in harmony without hurting of insulting each other's instincts. The attitude of dialogue should not be aggressive, it teaches the viewers and its followers that every religion and its followers must be given due respect. It significantly improves a person's understanding of the other person. While the person can learn a significant amount about another religion from books, talking to people who practice that religion about what they believe, what they do and how they feel about it transforms a person's knowledge and more importantly his/her understanding. It enhances understanding, goodwill and a sense of community between people of different faiths.

- Inter-faith dialogue can be helpful in removing the fear from the minds of the minorities who are oppressed and help them to co-operate with the majority community in the field of development and prosperity of the nation.

- Interfaith dialogue helps to explore and learn about each other and know more about the traditions of one's faith. Every person's inner soul is in search for a deep understanding of the truth that includes Almighty God, the Universe and the Life etc. The process of dialogue helps the participants and the viewers to get an insight of the concepts of truth in other religions which will help them to get a clear vision of the different aspects of truth. Also the knowledge and insight of other religions will help to eradicate the misconceptions and misunderstandings of any particular religion.

- Dialogue between followers of different faith traditions helps each religion to grow and develop mutually. Each religion through dialogue helps other religion for its enrichment. Interfaith dialogue provides space for the religions to contribute and complement each other. It helps society as a whole by producing better mutual understanding among the believers of different religions 
- Dialogue between followers of different faith traditions encourages in supporting of each other in times of difficulty. When natural or man-made calamities strike upon the society, dialogue helps in creating people and individuals who do relief work irrespective of caste, creed, religion, language etc. They don't consider priorities in rendering their much needed services. They only see that their services are rendered in its proper channel to each and every one affected by the calamities. (the best example is during this pandemic COVID -19 in all parts of the world, people help each other irrespective of their religions.) As India reels from the effects of a nationwide lockdown since $25^{\text {th }}$ of March 2020. Many people were stuck at home alone, leaving the elderly especially feeling lonely and cut-off from family and friends. But While both the central and state governments are actively working on implementing new measures to battle COVID-19, and fixing logistical glitches in existing lockdown procedures, it is the ordinary citizens and their extraordinary acts of kindness that have proven to be a bright spot in this dark and desolate time. Along with all the fear and panic caused by the coronavirus, the pandemic has also seen kindness go viral across the globe, with neighbours and complete strangers pitching in to help. 84.26 lakh people have been provided meals across the country during the lockdown, of which nearly $37 \%$ people were fed by Non-governmental organisations (NGOs). In Gujarat, NGOs fed 93\% of the people who were provided meals, while in Andhra the figure was $92 \%$ and all this has been done without knowing each other's religion.

- Doctors in India, like elsewhere, are on the front lines fighting the pandemic, and they are often working around the clock. Their anxiety and stress levels at work are immense, but through this tough journey, they had helped lots of people irrespective of their religions.

- Likewise, when any individuals of any particular religion suffer economically or physically he will be looked after and taken care of by the members of the other religious groups without considering his religion. This mind can be set up and build very strongly with the help of interfaith dialogues. There are many moral stories which expose the moral values or are brought as examples for a particular moral value in every religion. These stories of morality and virtue can be exchanged in the process of interfaith dialogue which will be quite helpful to the recipients in inducing those values among its followers.

- Interfaith dialogue helps the people with whom you are talking to understand any religion. The experience of dealing with anyone is limited to situations such as the workplace where you never talk in any depth about your religion, what you practice and how you feel about it. By taking part in interfaith dialogue, you can help each other to understand that the people who follow other religions are intelligent, sympathetic who can discuss their differences with members of other religions while remaining completely confident in their own.

- Dialogue between followers of different faith traditions is of great help to achieve common goals of the society and nation. It enhances the participation of every member of every religion in the development and prosperity of the nation. Dialogues help in making public opinion against the evils prevailing in the society and thus result in its eradication from the society. Dialogues minimize the gap between communities which in turn reinforces the national integration of a country. "All human beings are entitled to participate in the activities that will shape the world in the third millennium. No nation should be left on the side-lines because of some philosophical, political or economic argument. It is not enough to tolerate others but one must work with others. The human world must be shaped by the massive cooperation of all human beings. Though this notion up to the early $20^{\text {th }}$ century sounded like a humanist motto, today it is a necessity for the continuation of human life." 12

- All religions believe in selfless service to humanity. With the help of interfaith dialogue, the services and aids can be extended to the people of other religions also. Muslim have a remarkable historical background of good communal bonds with other communities. Islam itself encourages and teaches its followers to maintain communal harmony with members of other religions. During the festive seasons religious organizations can give more attention to such activities. During the month of Ramadan in India there are many organizations and political parties which extend their aids and distribute relief funds among the needy regardless of their religion.

- If there are some joint activities in this regard it will bring good results and thrust for peaceful co-existence. This group of religious leadership can run schools and hospitals and other institutions and funding agencies jointly in areas where people of different religious denomination resides and create an atmosphere where people of different religions can interact peacefully.

- The paradoxical benefit of engaging in interfaith dialogue is that it helps a person to understand his/her own religion much better. They may have been brought up practicing their religion but that is not the same as studying it in depth to find out how it addresses fundamental issues. When a person preparing for any formal interfaith dialogue discussions, they have to do a significant amount of research on the scripts of their own religion as it is essential to put forward propositions which are firmly grounded in the texts rather than being at risk of simply conveying the own assumptions about what the person think of his/her religion.

\section{Conclusion}

To conclude I would say, the Dialogue between followers of different faith traditions is not about conversion. It is the best practical expression of peace and harmony. It does not mean to accept one's religion but it is essential to stand-in communal harmony as well as teaching you about the other religions, engaging in it helps you to understand your own religion better. To combat communal hatred and promote inter-community harmony, people of different faiths must strive to promote a culture of dialogue. People should work together to make the world better. They should be able to make the ways to come out of the dangers of the modern technocracy and environmental devastation, energy crises, youth problems, hunger, violent radicalism and decadence of morality and faith. In addition, every human being should 
have the ability to discuss their religious and cultural differences which is very important in a democratic society such as ours that is filled with people whose differences are deep and complex in nature. Dialogue between followers of different faith traditions can be an excellent way to heal divisions in society. Social science research indicates that having a positive, meaningful relationship with someone of a different background and learning about their identity correlates to viewing that person's entire group more favorably. The same logic applies with interfaith conversations. It is also experienced that the discussion and study about any other religion helps one to be more acquainted and have deep knowledge in his own religion.

The good aspects of every religion should be taught in schools and seminaries and in upper level religious parliaments can be organized for the exchange of ideas and views about religion in the presence of religious scholars. Such exchanges will help form reasonable ideas of coexistence in students. Further the interfaith dialogue between Hindus, Muslims, Christians, and Sikhs will help in removing partialities and misunderstandings about one another and help to realize common objectives such as the establishment of peace and justice in the world, the protection of families from disintegration, the fortification of human rights and the promotion of moral values. In this context of interfaith dialogue, there are three categories of people to deal with. First are those who have the will and inclination to understand the fundamentals of other faith. This group tries to read, learn and understand about other religion through various means. The second group of people is those who have an allergy towards other religion. They have fixed opinion about other religion and do not want to listen anything positive about any faith. The third group of people have empty mind towards other faith. They fall prey to many misconceptions about other faiths. The challenge before those working towards interfaith dialogue of religions in India is to engage all the three categories of people and reach out to them with the message of humanity and peaceful coexistence. It is very important for our future generations. Our discourses today, would pattern their lives in tomorrow. Now it is in our hands that, do we want to give them the better future in which they would turn to be more tolerant and adamant about the needs of peace and amity in the world or make them the pessimists who would fetch on the ever deviating humanity.

\section{References}

1. Hans Kung, Global Responsibility, USA: Stock Publishers, 2004, 56.

2. Perelman $\mathrm{CH}$, Olbrechts- Tyteca L. The new rhetoric: A treatise on argumentation. Notre Dame, IN: University of Notre Dame Press, 1969 1969, 37.

3. Gulen MF. "Necessity of interfaith dialog." The Fountain Magazine. 2000, 31.

4. Ahmet Kurucan, Mustafa Kasim Erol "Dialogue in Islam Qur'an - Sunnah - History" published in Great Britain 2012, 20

5. Rev. Mary Katherine Allman, Chaplaincy Amidst Religious Diversity, Published by the National Association of Episcopal Schools, The Network, 1999

6. Pinto, Henrique. Foucault, Christianity and interfaith dialogue. New York, Routledge Publications, Psychology Press, 2003.
7. Leonard Swidler, Khalid Duran, Reuven Firestone, Trialogue: Jews, Christians and Muslims in Dialogue. New London, CT: Twenty-Third Publications, 2007

8. Interreligious Dialogue, Berkley Center for Religion, Peace and World Affairs, Washington, DC, 2007, (https://berkleycenter.georgetown.edu/resources/interrel igious-dialogue)

9. Said by Hans Kung, a professor emeritus of ecumenical theology and president of the Global Ethic Foundation, quoted by: Musser, D \& Sunderland, D., War or Words: Interreligious Dialogue as an Instrument of Peace Cleveland: The Pilgrim Press, 2005, 1.

10. Smock DR. Interfaith Dialogue and Peacebuilding. Washington, DC: United States Institute of Peace, 2002.

11. Mahatma Ghandi; http://www.leadthecompetition.in/GK/history/important -quotes-of-gandhiji.html

12. Syed Mohammed Khatimi, Islam, Dialogue, Civil Society, 32.

13. Abu-Nimer M, Khoury A, Welty, Unity in diversity: Interfaith dialogue in the Middle East. Washington, DC: United States Institute of Peace, 2007.

14. Ahmet Kurucan, Mustafa Kasim Erol "Dialogue in Islam Qur'an - Sunnah - History" published in Great Britain, 2012.

15. Amir Hussain. "Muslims, Pluralism, and Interfaith Dialogue," in Progressive Muslims: On Justice, Gender, and Pluralism, ed. Omid Safi, Oneworld Publications, 2003.

16. Ariarajah, Wesle S. Not Without My Neighbor: Issues in Interfaith Relations. WCC (World Council of Churches), 1999.

17. Braybrooke M. Pilgrimage of Hope: One Hundred Years of Global Interfaith Dialogue. Crossroad Publishing, 1992.

18. Carmody, Denise, Lardne J. Mysticism: Holiness East and West. Oxford University Press; 1 edition, 1996.

19. Catharine Cookson, ed., Encyclopedia of Religious Freedom. Taylor \& Francis, 2003.

20. Catherine Cornile, The Im-Possibility of Interreligious Dialogue, Crossroad Publishing Company, 2008.

21. Cosijns LF, Braybrooke M. Dialogue among the faith communities, Hamilton Books, Lanham, USA, 2008.

22. Cracknel K. Justice, Courtesy and Love: Theologians and Missionaries Encountering World Religions 18461914. Epworth, 1995.

23. Crowley S. Toward a civil discourse: Rhetoric and Fundamentalism, University of Pittsburgh Press, Pittsburgh, 2006.

24. Daniel Yankelovich. The Magic of Dialogue, (New York: Simon and Schuster, 1999.

25. Eck, D. The New Religious America: How a "Christian Country" has Become the World's Most Religiously Diverse Nation. Harper San Francisco, 1992.

26. Forward M. Interreligious Dialogue; A Short Introduction. Oneworld, 2001.

27. Gulen MF. "Necessity of interfaith dialog." The Fountain Magazine. 2000, 31.

28. Hans Kung, Global Responsibility, USA: STOCK Publishers, 2004.

29. Hick, John, ed. Truth and Dialogue: The Relationship between World Religions, in series, Studies in Philosophy and Religion. London: Sheldon Press, 1974. 
30. Hick J. An Interpretation of Religion: Human Responses to the Transcendent, 2nd ed. Yale University Press, 2005.

31. Kot Z. "Muslim-Christian relations: The traditionalist interfaith dialogue" (Unpublished thesis) George Washington University, Washington, DC, 2009.

32. Kung H. Global Responsibility: In Search of a New World Ethic. Crossroad Publishing, 1991.

33. Leonard Swidler, Khalid Duran, Reuven Firestone. Trialogue: Jews, Christians and Muslims in Dialogue. New London, CT: Twenty-Third Publications, 2007

34. Martin Buber, I and Thou, (New York: Simon and Schuster, 1971.

35. Moulin-Stożek, Daniel, "How do we see each other? Interdisciplinary and the potential of interreligious scholarship". Journal of Beliefs \& Values. 2017, 38.

36. Musser D, Sunderland D. War or Words: Interreligious Dialogue as an Instrument of Peace Cleveland: The Pilgrim Press, 2005.

37. Nasr SH. The Essential Frithj of Schuon (Library of Perennial Philosophy). World Wisdom, 2005.

38. Perelman $\mathrm{CH}$, Olbrechts- Tyteca L. The new rhetoric: A treatise on argumentation. Notre Dame, IN: University of Notre Dame Press, 1969.

39. Pinto, Henrique, Foucault, Christianity and interfaith dialogue. New York, NY: Routledge Publications, Psychology Press, 2003

40. Race A. Christians and Religious Pluralism: Patterns in the Christian Theology of Religions. Orbis, 1983.

41. Rev. Mary Katherine Allman, Chaplaincy Amidst Religious Diversity, Published by the National Association of Episcopal Schools, The Network, 1999

42. Roy choudhury ML. The Din-I-Ilahi Or the Religion of Akbar. All Time Books, 1997.

43. Seager RH. The Dawn of Religious Pluralism: Voices from the World's Parliament of Religions 1893. Open Court, 1993.

44. Smock DR. Interfaith Dialogue and Peacebuilding. Washington, DC: United States Institute of Peace, 2002.

45. Swami Abhishiktananda, Hindu-Christian Meeting Point: Within the Cave of the Heart. Indian Institute of Culture, Bangalore, 1969.

46. Swidler L, Duran K, Firestone R., Trialogue: Jews, Christians and Muslims in Dialogue. New London, CT: Twenty-Third Publications, 2007.

47. Syed Mohammed Khatimi, Islam, Dialogue and Civil Society, The Australian National University, 2000.

48. Wattles, Jeffrey. The Golden Rule, Oxford University Press. 1996 